\title{
Replicated marine protected areas (MPAs) support movement of larger, but not more, European lobsters to neighbouring fished areas
}

\author{
Susanna Huneide Thorbjørnsen ${ }^{1,2, *}$, Even Moland ${ }^{1,2}$, \\ Mats Brockstedt Olsen Huserbråten ${ }^{1,2}$, Jan Atle Knutsen ${ }^{1}$, Halvor Knutsen ${ }^{1,2}$, \\ Esben Moland Olsen ${ }^{1,2}$
}

${ }^{1}$ Institute of Marine Research, Nye Flødevigveien 20, 4817 His, Norway

${ }^{2}$ Centre for Coastal Research, Department of Natural Sciences, Faculty of Engineering and Science, University of Agder, 4604 Kristiansand, Norway

\begin{abstract}
The European lobster Homarus gammarus is heavily exploited in the Norwegian fishery, and several management actions have been implemented to protect the species. Three marine protected areas (MPAs) excluding all but hook and line type fishing gear were established along the Skagerrak coast in 2006, effectively banning the trap-based fishery for European lobster. Lobster populations within MPAs and adjacent control areas were studied by capture-markrecapture and recovery methods every year from prior to MPA establishment to the present. During 2006-2014, a total of 4682 and 3317 lobsters were captured (including recaptures) in the MPAs and control areas, respectively. In all MPAs, protection led to a shift in demography, with an increase in mean total length of $15 \%$ during 2006-2014, thereby opposing the effects of a sizeselective fishery. No difference was found in rates of movement out from MPAs and control areas, but lobsters moving from MPAs and caught in fished areas were significantly larger than lobsters moving out of control areas. In instances where lobsters tagged in a control area moved into an MPA, the immigrating lobsters had a larger body size than the mean in their area of origin. The range of movement undertaken by recovered lobsters extended beyond the home range sizes suggested by previous shorter-term studies, and well beyond the sizes of the small coastal MPAs studied herein. In summary, demographic changes should be accounted for when interpreting the value of spillover from MPAs, and also potential 'spill in' from fished areas to MPAs.
\end{abstract}

KEY WORDS: Marine reserve design - Bathymetry · Demography - Spillover · Homarus gammarus · Tag return

\section{INTRODUCTION}

Marine protected areas (MPAs) are widely used for conservation and fisheries management. Some MPAs are strictly no-take zones (marine reserves), while others are designed to protect a part of the ecosystem or certain target species through specific restrictions. Marine reserves are expected to increase both abun-

\footnotetext{
*Corresponding author: susanna.thorbjornsen@gmail.com
}

dance and biomass of the protected species inside the reserve relative to non-protected areas (Lester et al. 2009). European marine reserves have supported an increase in biomass $(238 \%)$, density $(116 \%)$ and body size $(13 \%)$ of protected species, and in some cases protection has also led to an increase in species richness (19\%) (Fenberg et al. 2012). An increase in abundance and/or biomass within reserves may (C) The authors, Institute of Marine Research (Norway), and Centre for Coastal Research (University of Agder, Norway) 2018. Open Access under Creative Commons by Attribution Licence. Use, distribution and reproduction are unrestricted. Authors and original publication must be credited.

Publisher: Inter-Research · www.int-res.com 
result in spillover of adults to adjacent areas. Spillover is defined as net export of individuals from a protected area to an adjacent area open to fishing (Abesamis \& Russ 2005, Goñi et al. 2006), and can develop as an effect of both density-independent (e.g. movement within a home range, nomadism, adult migration and ontogenetic migrations) and density-dependent (e.g. competition) factors (Gruss et al. 2011). Quantifying connectivity between MPAs and adjacent fished areas is thus of importance when assessing the benefit of MPAs to fisheries (Roberts et al. 2001, Abesamis \& Russ 2005, Kerwath et al. 2013).

Reported catches of European lobster Homarus gammarus in Norway have been in decline since the 1960s (Pettersen et al. 2009). Successful rebuilding of lobster populations through the use of MPAs has been reported across species and latitudes (e.g. Edgar \& Barret 1999, Goñi et al. 2006, Bevacqua et al. 2010, Hoskin et al. 2011, Moland et al. 2013). However, direct quantification of the contribution spillover makes to the lobster fishery is rare (but see Goñi et al. 2010). Earlier studies suggest that movement out of MPAs typically occurs when boundaries intersect preferable lobster habitat (Smith et al. 2001, Freeman et al. 2009, Moland et al. 2011b). Movement patterns in relation to habitat are of interest in order to achieve efficient MPA design in compliance with management goals (Follesa et al. 2009, Moland et al. 2011b). European lobsters typically prefer habitats including, or in proximity to, rocky bottoms (Galparsoro et al. 2009). Also, bathymetry, including both depth and slope, are significant variables for assessing lobster distributions (Galparsoro et al. 2009, Moland et al. 2011a).

Although increases in density can support spillover (Goñi et al. 2010), a more natural size distribution within a protected area may provide additional benefits. In a study of fisheries in the California Current, Anderson et al. (2008) recognized how a selective harvesting regime targeting older and larger individuals of the population led to instability of population dynamics, making the age-truncated populations less resistant to environmental fluctuations. Selective targeting of larger and older individuals has also, until recently, been the practice in the European lobster fishery in Norway as a consequence of minimum legal size restrictions. MPAs protecting lobsters could thus contribute to stabilizing the population dynamics that are disrupted by the size-selective fishery, in turn increasing the resilience of the lobster population in Norway and potentially provide a more attractive area resulting in 'spill-in' to the reserve (Eggleston \& Parsons 2008).
The overall aim of this study was to investigate the pattern and magnitude of movement from 3 MPAs situated along the southern coast of Norway. A potential spillover effect was assessed by comparing research survey and fishery data on lobsters originating from MPAs and control areas in the form of tag returns, allowing evaluation of distance and directionality of movement. Specifically, we tested the hypothesis that the increase in both abundance and size of individuals that followed protection of European lobster in MPAs (Moland et al. 2013) would support increased spillover of adult lobsters to adjacent areas.

\section{MATERIALS AND METHODS}

\section{Study species}

The European lobster is distributed from Morocco to northern Norway (Triantafyllidis et al. 2005) and is a popular target of commercial and recreational fisheries (Kleiven et al. 2012). Lobsters prefer rocky habitats at depths down to about $60 \mathrm{~m}$ (Galparsoro et al. 2009). Movement is often limited to a few $\mathrm{km}$ (Moland et al. 2011b, Wiig et al. 2013), but exceptions include movements of up to tens of $\mathrm{km}$ (Smith et al. 2001, Agnalt et al. 2007, Huserbråten et al. 2013). In southern Norway, lobsters can be fished from 1 October until 30 November. The minimum legal size is $25 \mathrm{~cm}$ total length (24 cm before 2008), measured from the tip of the rostrum to the posterior margin of the telson. A maximum legal size at $32 \mathrm{~cm}$ total length was introduced in 2017. As of 2008, there is a ban on landing and trade of egg-bearing females. Lobster traps are the only permitted gear, and these need to have 2 escape vents of $60 \mathrm{~mm}$ in diameter to allow lobsters below the minimum legal size to escape.

\section{Study system}

Three MPAs protecting lobster were established in the southern part of Norway in September 2006: the Bolærne MPA in the outer Oslofjord $\left(0.7 \mathrm{~km}^{2}\right)$, the Flødevigen MPA in Arendal $\left(1 \mathrm{~km}^{2}\right)$ and the Kvernskjær MPA in Hvaler $\left(0.5 \mathrm{~km}^{2}\right)$ (Fig. 1). Fishing restrictions include a ban on the use of all types of passive fishing gear, excluding hook and line equipment. A control area approximately matching the MPA size and habitat was designed at all sites (Fig. 1). Information on the habitat in the areas was 

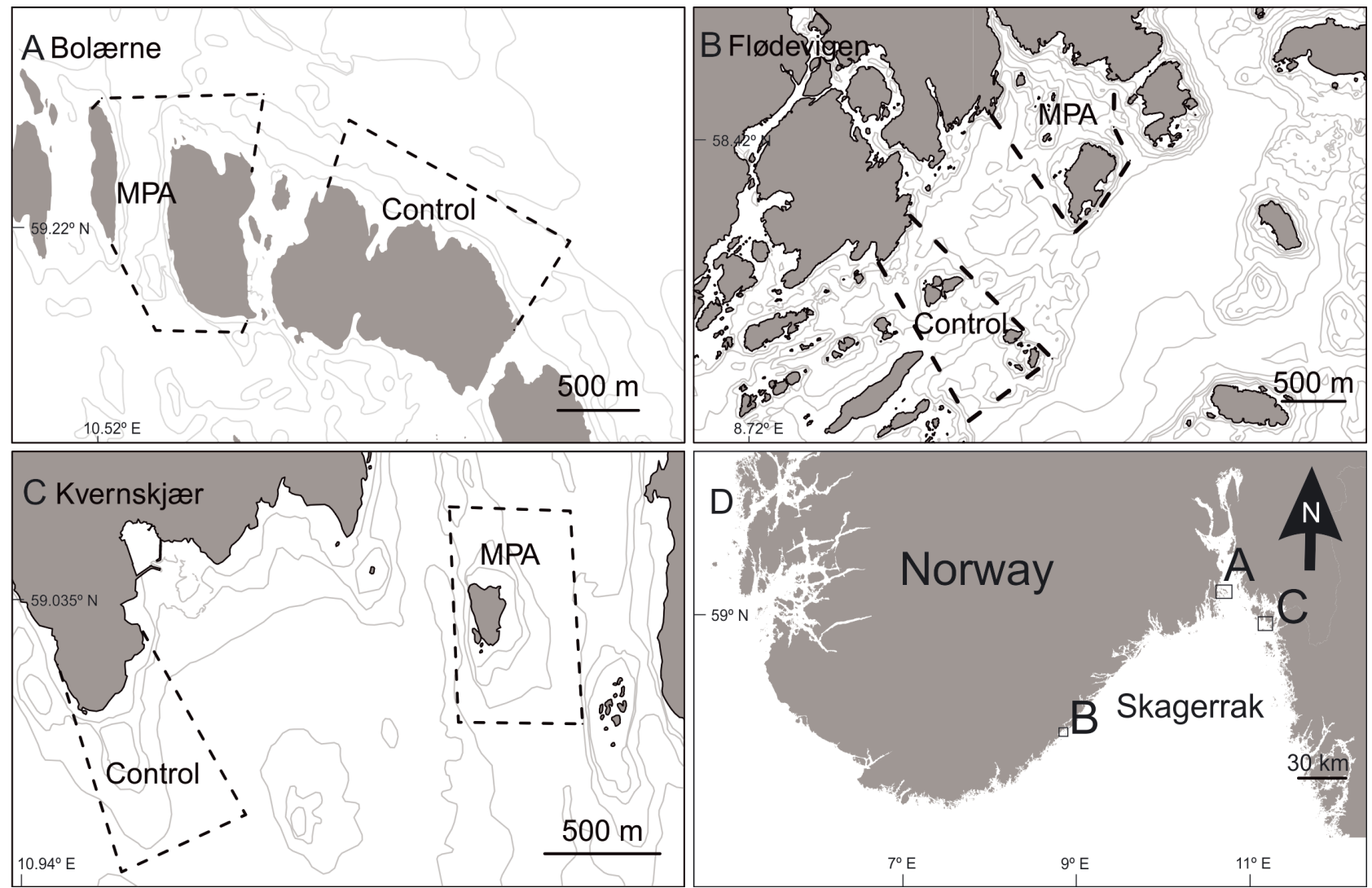

Fig. 1. Location of the studied marine protected areas (MPAs) in Skagerrak. MPAs and control areas in (A) Bolærne, (B) Flødevigen and (C) Kvernskjær in Vestfold, Aust-Agder and Hvaler counties, respectively. (D) Skagerrak Sea

obtained by SCUBA surveys. All areas chosen are examples of typical lobster habitats found in the Skagerrak, and site selection was based on 4 additional criteria, as described by Pettersen et al. (2009, p. 180):

'The areas should (a) have an acceptable lobster population, (b) have a habitat suitable to hold a substantial lobster population, (c) be effective to monitor and (d) be supported by local commercial fishers.'

The Bolærne MPA (Fig. 1A) comprises a narrow trench between 2 islands where steep slopes end in a flatter area reaching down to 26-31 m. The MPA continues around the northern and southern part of Vestre Bolæren island where depths do not exceed $23 \mathrm{~m}$. The adjacent control area is situated $475 \mathrm{~m}$ east of the MPA and follows the northern margin of the Midtre Bolæren island. There are continuous depth curves along the northern edge of the 3 islands, indicating a potentially continuous lobster habitat. Maximum depth of the control area is $41 \mathrm{~m}$. The Flødevigen MPA (Fig. 1B) includes Flødevigen bay, several smaller islands and 1 larger island. The depth profile ranges from 0 to $32 \mathrm{~m}$, with the exception of a steep rock slope which intercepts the southeastern border of the MPA at $40-50 \mathrm{~m}$ depth and slopes down to $90 \mathrm{~m}$ outside the MPA. Rock faces and boulder fields dominate the area, with some additional flat areas of soft sediments. The adjacent control area is located $785 \mathrm{~m}$ southwest of the MPA. It includes a small stretch of coast and 2 groups of small islands. The habitat is similar to that of the adjacent MPA and also has a steeper slope intercepting the southeastern border, directed towards the same deeper basin. The area between the MPA and control area includes several submerged shoals with depths ranging from 3 to $14 \mathrm{~m}$, surrounded by deeper areas with depths reaching a maximum of $35 \mathrm{~m}$. The Kvernskjær MPA (Fig. 1C) encircles the Kvernskjær Island and consists of rock faces and boulder fields continuing down to $55 \mathrm{~m}$ with the steepest slope situated on the western side. Flat areas with soft sediments are also present. The adjacent control area is located $1005 \mathrm{~m}$ southwest of the MPA and starts off the edge of a small peninsula. It contains less steep rock and fewer boulder fields than the MPA, reaching down to $36 \mathrm{~m}$. 
A trench with depths ranging from 34 to $58 \mathrm{~m}$ separates the MPA from the control area.

\section{Data collection}

Movement of lobsters was assessed by capturemark-recapture (CMR) data from the 3 MPAs and adjacent control areas, in addition to reported recoveries from lobster fishers, herein referred to as 'recoveries'. The MPAs and control areas were monitored in August/September every year from establishment in 2006 to 2014. Sampling effort in both MPAs and control areas was 100 trap days $\mathrm{yr}^{-1}$ study site ${ }^{-1}$, and each trap had a soak time of about $24 \mathrm{~h}$ (25 traps $\times$ $4 \mathrm{~d}=100$ trap days). The research traps did not have escape vents. Lobsters captured for the first time were tagged with individually numbered T-bar anchor tags (Hallprint). The tags were inserted in the ventral musculature between the cephalothorax and abdomen to minimise tag loss during moulting (Moland et al. 2013). The lobsters were sexed, tagged and measured for total length (TL) and subsequently released at the capture location. TL was measured to the nearest $\mathrm{mm}$ from the tip of the rostrum to the posterior margin of the telson (Moland et al. 2013). The process was repeated for control areas, where lobster fishing is allowed in October and November. Information on tagged lobsters recovered outside the MPAs, or in and around the control areas was reported by fishers each year since the tagging started. Reports included in this study contain information on time and approximate place of capture (described in relation to well-known islands, submerged rocks, navigational markers etc.) or exact place of capture (GPS coordinates). Reports from fishers were delivered on a voluntary basis without a reward system.

\section{Data analyses}

All modelling was conducted in the statistical software R (R Core Team 2014). Temporal changes in size distributions of the study populations were quantified. Distance moved was calculated as the Euclidean distance between capture and recapture position. Lobster movement was assessed inside MPAs and control areas, between MPAs and control areas, and from MPAs and control areas to fished grounds. Movement data from within the MPAs and control areas had time intervals with a minimum duration of $1 \mathrm{yr}$, while all time intervals were included for recoveries/recaptures outside the area of origin. To inves- tigate the extent and direction of lobster movement at the different study sites, recoveries from fishers were visualized in bathymetric maps. Polar diagrams were used to show the direction and relative distance of lobster movement. To quantify the movement of lobsters from the MPAs and control areas to fished areas, recoveries of lobsters tagged in the respective areas were used. All lobsters recovered within the control area were omitted to enable comparison with MPA lobsters, which cannot be recovered inside the MPA as a consequence of the management regulations. As no data were available on lobster movement from fished areas (outside of designated control areas) to MPAs, net movement from MPAs could not be calculated. Spillover was thus evaluated indirectly by comparing export to fished areas from MPAs and control areas. To test if there was more movement from MPAs to fished areas, compared to the movement from control areas to fished areas, a Pearson's chi-squared 2-sample test for equality of proportions was used, based on the total number of tagged lobsters in the respective areas. This was to account for the unequal number of tagged lobsters in the MPAs and control areas. Additionally, a Pearson's chisquared 2-sample test was used to evaluate whether there was more movement (in numbers) from MPAs to fished areas than from control areas to fished areas.

To describe the distribution of fishers around the MPAs and nearby control areas, the distance from each recovery position to the centre point of the MPA and the control area was calculated. A 1-sample $t$ test was used to test the null hypothesis that the difference in these distances was not significantly different from 0 for each study site, and thus indicates an even distribution of fishers. The test was repeated for all study sites.

To test the effect of the MPA treatment on the size (TL) of recovered lobsters, a linear mixed-effects (LME) model with a random intercept (Zuur et al. 2009) was fitted to the data using 'Origin' (factor levels: MPA and control, defined as the area where the lobster was first tagged) as a fixed effect. The random effect variable 'Site' represents the 3 study sites (levels: Bolærne, Flødevigen and Kvernskjær). To test if there was any difference in distance moved by lobsters originating in an MPA and lobsters originating in a control area (variable 'Origin') to the position of recovery in the fished area, an LME model with a random intercept (random effect variable 'Site') was fitted to the data. The variable 'Distance' was logtransformed for normality. The distance was measured from the most recent position of observation in the original tagging area to the position of recovery. 
Movement between the MPA and control area was quantified using recapture data from the CMR survey. To assess differences in spillover or 'spill-in' among areas, Pearson's chi-squared 2-sample tests

Table 1. Numbers of European lobsters that were newly tagged, recaptured and recovered by lobster fishers in marine protected areas (MPAs) and control areas at all study sites for all years. The recovered lobsters were caught in fished areas at each study site and are sorted by their area of origin

\begin{tabular}{|c|c|c|c|c|c|c|}
\hline Year & \multicolumn{2}{|c|}{$\begin{array}{c}\text { Bolærne } \\
\text { MPA Control }\end{array}$} & \multicolumn{2}{|c|}{$\begin{array}{c}\text { Flødevige } \\
\text { MPA Control }\end{array}$} & \multicolumn{2}{|c|}{$\begin{array}{l}\text { Kvernskjær } \\
\text { MPA Control }\end{array}$} \\
\hline \multicolumn{7}{|c|}{ Newly tagged } \\
\hline 2006 & 70 & 50 & 65 & 48 & 51 & 110 \\
\hline 2007 & 137 & 91 & 35 & 30 & 106 & 90 \\
\hline 2008 & 105 & 62 & 65 & 44 & 112 & 154 \\
\hline 2009 & 249 & 157 & 64 & 40 & 118 & 161 \\
\hline 2010 & 186 & 102 & 36 & 52 & 120 & 132 \\
\hline 2011 & 104 & 61 & 75 & 39 & 139 & 214 \\
\hline 2012 & 209 & 128 & 77 & 41 & 138 & 180 \\
\hline 2013 & 168 & 96 & 60 & 41 & 105 & 158 \\
\hline 2014 & 99 & 67 & 49 & 27 & 51 & 84 \\
\hline \multicolumn{7}{|c|}{ Recaptures } \\
\hline 2006 & 5 & 2 & 3 & 6 & 1 & 15 \\
\hline 2007 & 34 & 7 & 25 & 3 & 56 & 24 \\
\hline 2008 & 66 & 15 & 29 & 11 & 77 & 24 \\
\hline 2009 & 48 & 29 & 52 & 11 & 104 & 84 \\
\hline 2010 & 128 & 45 & 75 & 12 & 131 & 75 \\
\hline 2011 & 76 & 21 & 17 & 8 & 158 & 105 \\
\hline 2012 & 71 & 30 & 33 & 7 & 147 & 97 \\
\hline 2013 & 100 & 42 & 70 & 11 & 177 & 81 \\
\hline 2014 & 66 & 32 & 46 & 7 & 94 & 54 \\
\hline \multicolumn{7}{|c|}{ Recoveries in fished areas by area of origin } \\
\hline 2006 & 0 & 1 & 1 & 7 & 0 & 0 \\
\hline 2007 & 2 & 1 & 0 & 3 & 3 & 3 \\
\hline 2008 & 2 & 2 & 2 & 3 & 3 & 1 \\
\hline 2009 & 5 & 6 & 5 & 4 & 0 & 7 \\
\hline 2010 & 15 & 14 & 6 & 13 & 3 & 5 \\
\hline 2011 & 15 & 14 & 5 & 10 & 0 & 3 \\
\hline 2012 & 8 & 2 & 2 & 2 & 0 & 0 \\
\hline 2013 & 3 & 2 & 19 & 4 & 26 & 11 \\
\hline 2014 & 0 & 0 & 0 & 0 & 0 & 0 \\
\hline
\end{tabular}

for equality of proportions were used to compare directional movement between the MPA and control area. Recoveries from fishers were excluded in calculations involving the size and sex of moving lobsters, as reports of recoveries are expected to be biased towards lobsters larger than the minimum legal size, and as underreporting of egg-bearing females is expected. Consequently, only observations of lobsters moving between MPAs and control areas obtained in the CMR survey were used. To test if the sex ratio of moving lobsters differed significantly, a Pearson's chi-squared 2-sample test for equality of proportions was used. To test if the size (TL) of lobsters differed between lobsters sampled inside the control area and lobsters emigrating from the control area to the MPA, a linear model was created. The variable 'Status' had 2 levels: control lobsters sampled inside the control area and lobsters moving from the control area to the MPA. 'Sex' was also included as a predictor variable of 'TL'. The same model was used to test if the size (TL) of lobsters differed between lobsters sampled inside the MPA and lobsters emigrating from the MPA to the control area.

\section{RESULTS}

\section{Demography}

Totals of 4682 and 3317 European lobsters were captured (including recaptures) in the MPAs and control areas, respectively (Table 1). The temporal change in mean TL differed in the MPAs vs. the control areas (Table 2). There was an overall increase in mean TL in the MPAs that continued until the last year of sampling, with a total increase of $15 \%$ from 2006 to 2014 (Fig. 2). In contrast, there was an increase in mean TL of $1 \%$ from 2006 to 2014 in the control areas.

Table 2. Mean $\pm \mathrm{SE}$ total length $(\mathrm{cm})$ of European lobsters caught in marine protected areas $(\mathrm{M})$ and control areas (C) at all 3 sites for all years in the study

\begin{tabular}{|lcccccc|}
\hline Year & Bolærne M & Bolærne C & Flødevigen M & Flødevigen C & Kvernskjær M & Kvernskjær C \\
\hline 2006 & $24.2 \pm 0.30$ & $23.5 \pm 0.45$ & $24.1 \pm 0.35$ & $25.0 \pm 0.34$ & $23.2 \pm 0.51$ & $24.2 \pm 0.26$ \\
2007 & $24.5 \pm 0.28$ & $22.4 \pm 0.30$ & $25.6 \pm 0.47$ & $24.3 \pm 0.52$ & $24.5 \pm 0.26$ & $24.0 \pm 0.31$ \\
2008 & $25.7 \pm 0.29$ & $22.8 \pm 0.36$ & $26.7 \pm 0.42$ & $24.8 \pm 0.38$ & $24.6 \pm 0.25$ & $22.8 \pm 0.18$ \\
2009 & $25.3 \pm 0.20$ & $23.8 \pm 0.21$ & $27.6 \pm 0.34$ & $25.6 \pm 0.41$ & $25.6 \pm 0.20$ & $24.3 \pm 0.16$ \\
2010 & $27.2 \pm 0.19$ & $24.9 \pm 0.26$ & $27.6 \pm 0.35$ & $25.4 \pm 0.36$ & $26.0 \pm 0.21$ & $24.4 \pm 0.19$ \\
2011 & $27.0 \pm 0.24$ & $25.3 \pm 0.32$ & $26.7 \pm 0.32$ & $24.3 \pm 0.35$ & $26.6 \pm 0.19$ & $24.4 \pm 0.13$ \\
2012 & $26.7 \pm 0.19$ & $24.5 \pm 0.23$ & $28.2 \pm 0.36$ & $24.8 \pm 0.39$ & $27.4 \pm 0.21$ & $25.1 \pm 0.13$ \\
2013 & $26.4 \pm 0.21$ & $23.9 \pm 0.27$ & $28.4 \pm 0.35$ & $24.9 \pm 0.39$ & $27.3 \pm 0.21$ & $24.5 \pm 0.17$ \\
2014 & $27.4 \pm 0.28$ & $24.6 \pm 0.30$ & $27.8 \pm 0.37$ & $24.0 \pm 0.41$ & $27.1 \pm 0.27$ & $24.4 \pm 0.21$ \\
\hline
\end{tabular}



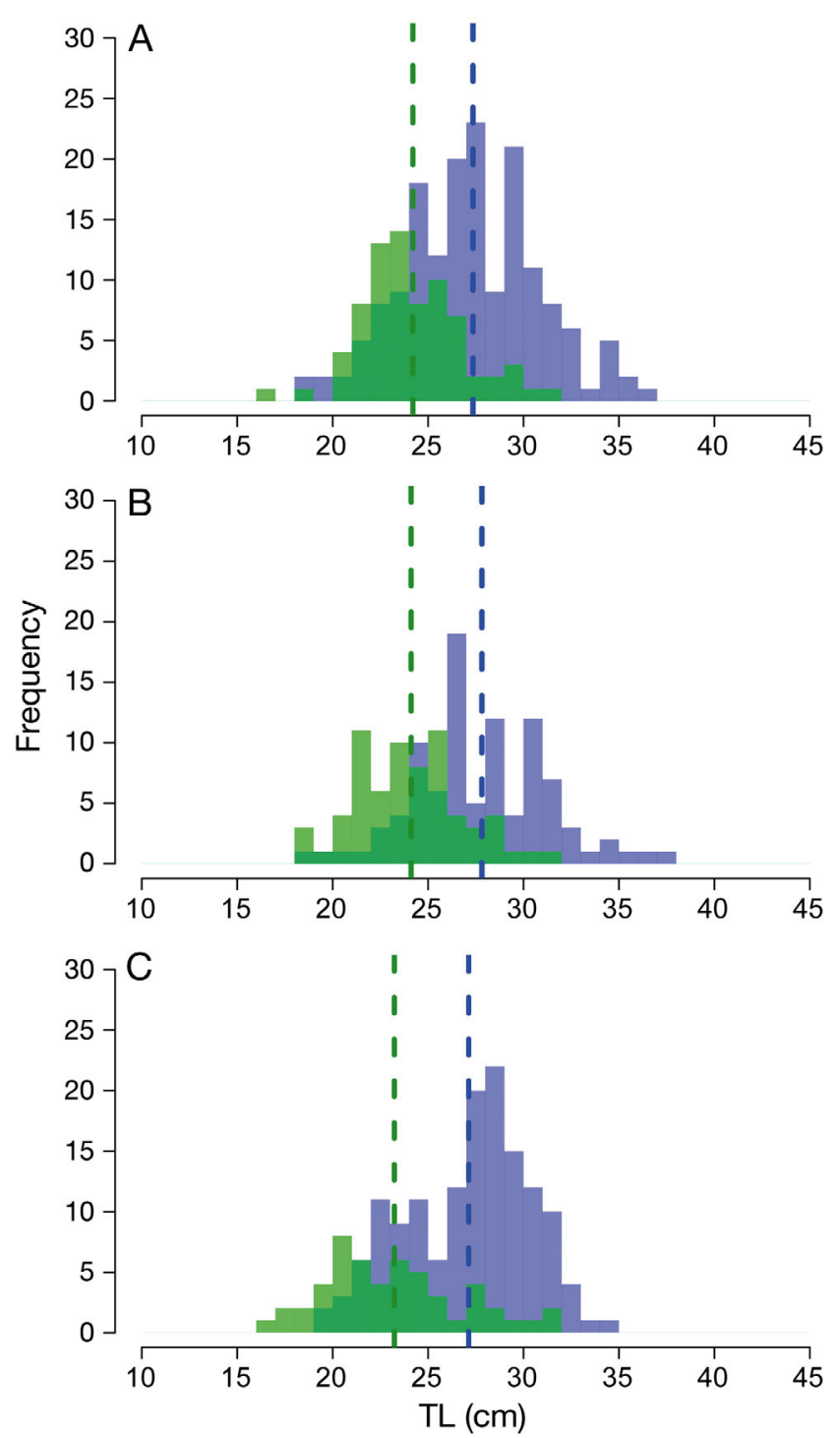

Fig. 2. Change in demography (total length, TL) of European lobsters Homarus gammarus. Shift in size distribution from the year of marine protected area establishment in 2006 to 2014 for (A) Bolærne, (B) Flødevigen and (C) Kvernskjær. Dashed lines show the change in mean TL from 2006 (green) to 2014 (blue). Overlap between the 2 distributions is shown in dark green

\section{Movement patterns - spatial range and directions}

A total of 331 lobsters were recovered and reported by commercial and recreational fishers in the period from 2006 to 2014. Recoveries made inside the control areas $(\mathrm{n}=88$ ) were excluded in all calculations, leaving a total of 243 recoveries (4.2\% of tagged lobsters) as the basis for our analyses (Table 1). The null hypothesis for an even distribution of recovered lobsters around the MPA and control area cannot be rejected for any of the study sites (Bolærne: $p=0.858$;
Flødevigen: $\mathrm{p}=0.290$; Kvernskjær: $\mathrm{p}=0.128$ ). During the same period, 1670 recaptures with a time interval of at least $1 \mathrm{yr}$ were made in the CMR survey. Among these, there were 48 observations of movement between MPAs and control areas.

The median distance moved by lobsters inside MPAs was $75 \mathrm{~m}$, with distances ranging from 4 to 1535 m (Fig. 3). Recovered lobsters originating from MPAs had a median movement distance of $1037 \mathrm{~m}$ (range: 35-24670 m). Inside control areas, the median distance moved by lobsters was $93 \mathrm{~m}$ (range: 11311 m; Fig. 3). Recovered lobsters originating from control areas had a median movement distance of 1047 m (range: 34-16 $690 \mathrm{~m}$ ).

Polar diagrams indicate that movement of lobsters varied among study sites (Fig. 4). Recoveries outside the Bolærne study site (Fig. 4A) were concentrated close to the island group, with decreasing density a few kilometres away from these areas. Recovery of MPA lobsters dominated south of the MPA border, while more control lobsters were recovered close to the control border and the eastern areas of the island group. Movements between the MPA and the control area were the most numerous here $(n=40)$. In Flødevigen (Fig. 4B), there was little mixing between the areas $(\mathrm{n}=3)$, with a high concentration of MPA lobsters recovered around the MPA borders and a high concentration of control lobsters recovered around the control borders. The recovery distribution in the Kvernskjær study site (Fig. 4C) showed little mixing of lobsters originating from the MPA and the control area, and movement between the areas was limited $(n=5)$. Most recoveries of MPA lobsters were distributed to the north, south and east of the trench between the MPA and control area. The majority of the control lobsters were recovered west of the control area, but some individuals were recovered east and north of the trench (Fig. 4C).

\section{Spillover and movement between MPAs and control areas}

At the Bolærne and Kvernskjær sites, there was no significant difference in movement from MPA to fished area vs. movement from control area to fished area (proportionality tests, p > 0.05). In Flødevigen, however, a significantly higher proportion of lobsters moved from the control area to the fished area than from the MPA to the fished area as a proportion of the total number of tagged lobsters in the MPA and the control area $(p=0.0398)$. However, when comparing the proportion of lobsters moving 


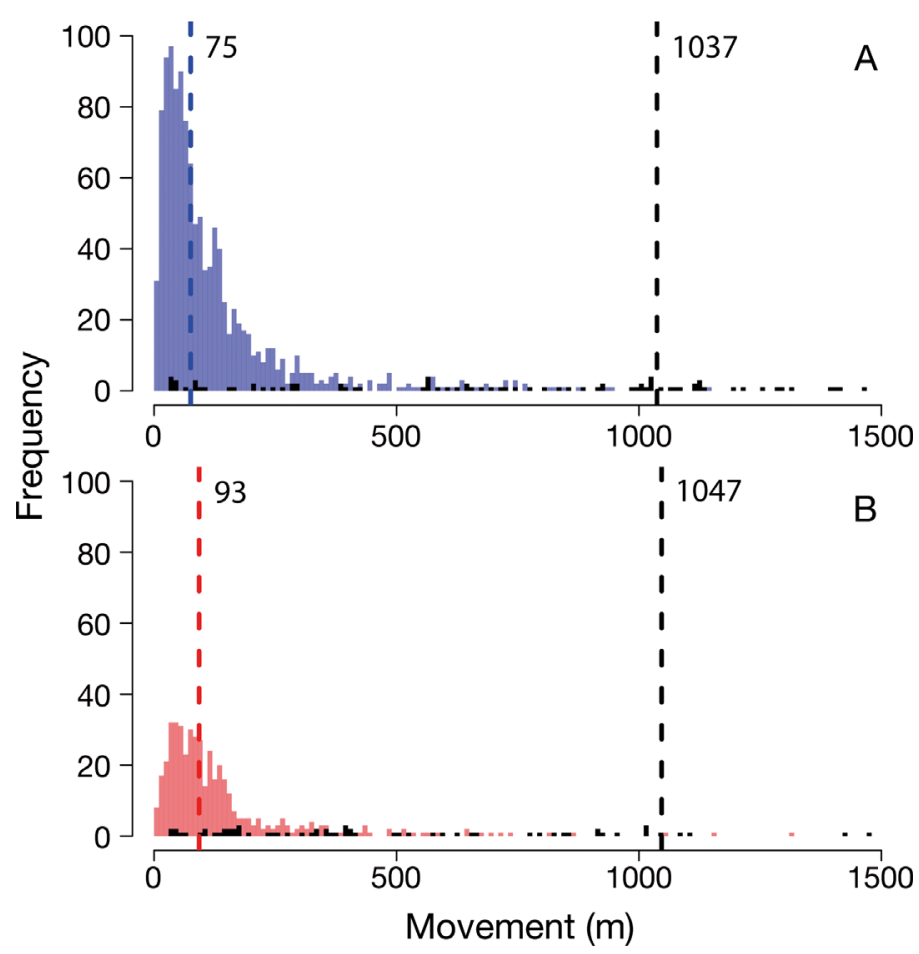

Fig. 3. Extent of movement undertaken by European lobsters tagged in (A) marine protected areas (blue) and (B) control areas (red) recaptured during the monitoring fishing, and $(A, B)$ those recovered and reported by fishers (black). Only movement observations of $<1500 \mathrm{~m}$ are shown. Vertical lines denote median distance moved for the different groups

out from the MPA and the control area based on the total number of emigrants in Flødevigen, there was no significant difference $(p>0.05)$. Movement between MPA and control area was limited in the 3 study sites with a total of 33 observations of lobsters moving from the control area to the MPA and 15 observations of lobsters moving from the MPA to the control area. A total of 27 and 13 of these observations, respectively, were registered at the Bolærne study site. The proportion of lobsters moving from the control area to the MPA was significantly higher than the proportion of lobsters moving in the opposite direction in Bolærne $(p<0.01)$. Observations of movement between MPA and control area were too few to compare directional movement between these in Flødevigen and Kvernskjær.

\section{Demography of moving lobsters}

Lobsters emigrating from the MPAs to fished areas were larger than lobsters emigrating from the control areas to fished areas $(\beta=1.19 \mathrm{~cm}, \mathrm{SE}= \pm 0.41 \mathrm{~cm}, \mathrm{df}$ $=225, \mathrm{p}<0.005)$. There was less variance between
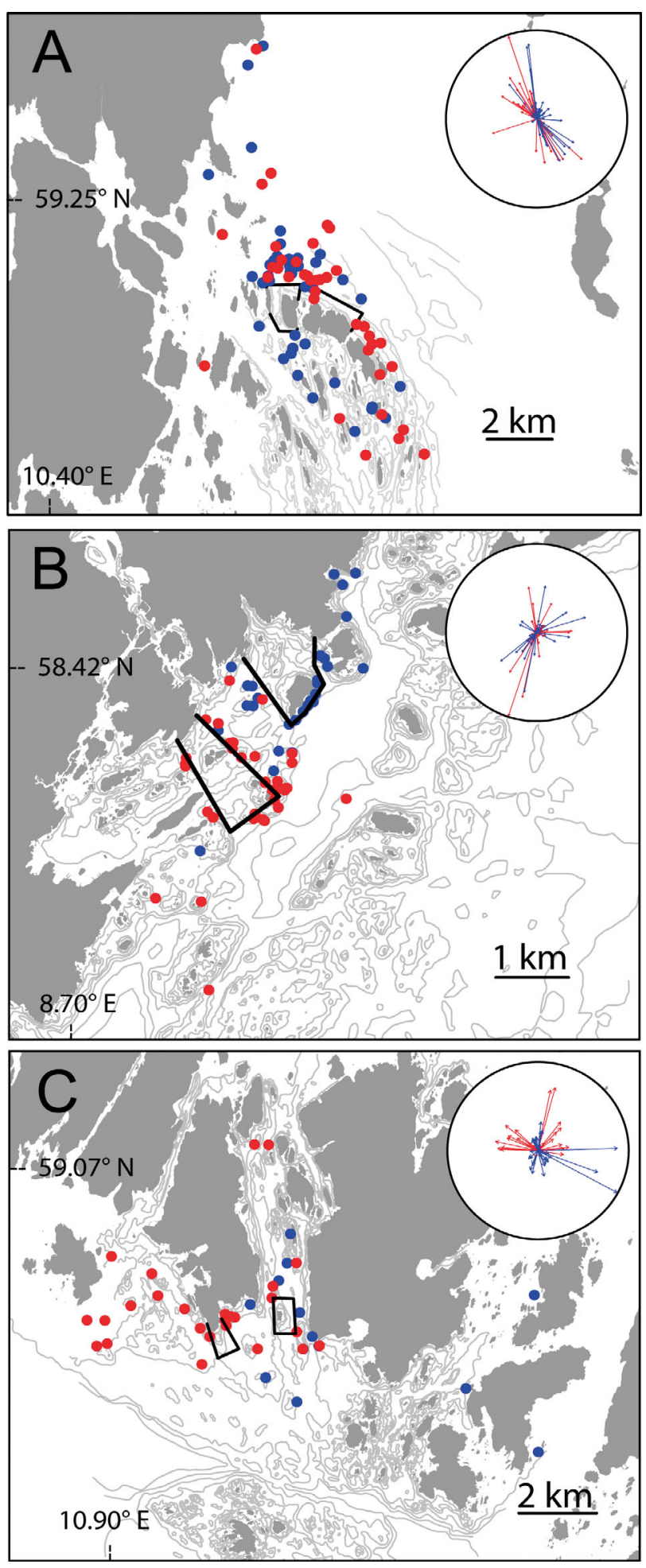

Fig. 4. Locations of European lobster tag recoveries reported by fishers. Blue: lobsters tagged in the marine protected areas (MPAs), red: lobsters tagged in control areas in (A) Bolærne, (B) Flødevigen and (C) Kvernskjær. MPAs and control areas are delineated in black (see also Fig. 1). Polar diagrams in the insets show the distribution of movement direction and relative distances 
the study sites than there was inside each study site, as the random effect 'Site' (Bolærne, Flødevigen and Kvernskjær) explained little of the residual variance $(<1 \%)$. There was no significant difference in distance moved for protected and unprotected lobsters to the position of recovery in the fished area $(\mathrm{df}=238$, $\mathrm{p}=0.211$ ).

Mean TL of lobsters moving from control areas to MPAs was larger than the mean TL of all lobsters captured in control areas $(\beta=1.83 \mathrm{~cm}, \mathrm{SE}= \pm 0.49 \mathrm{~cm}$, $\mathrm{df}=3347, \mathrm{p}<0.001)$. Sex was also significant, with male lobsters predicted to be larger than females ( $\beta=$ $0.38 \mathrm{~cm}, \mathrm{SE}= \pm 0.097 \mathrm{~cm}, \mathrm{df}=3347, \mathrm{p}<0.001)$. Proportions of male $(n=13)$ and female $(n=20)$ lobsters moving were not significantly different $(p=0.140)$. Females accounted for $60.6 \%$ of the recaptured individuals moving from control areas to MPAs, while females throughout the study accounted for $54.3 \%$ of the total number of recaptures in control areas. There was no significant difference in TL of lobsters moving from MPAs to control areas and lobsters sampled inside MPAs ( $\mathrm{df}=4693, \mathrm{p}=0.337$ ). Of the lobsters that were recaptured a second time after moving from their area of origin, only 1 out of 6 had left the MPA and none out of 2 left the control area.

\section{DISCUSSION}

This study quantifies movement of European lobsters from replicated marine MPAs and control areas throughout 9 yr. None of the MPAs generated more spillover of lobsters, in numbers, to fished grounds than their adjacent control areas. Nevertheless, lobsters moving out from the MPAs were significantly larger than lobsters moving out from control areas. The Bolærne study site supported the most movements between MPA and control areas, with more lobsters moving from the control area to the MPA than vice versa. Overall, lobsters moving from control areas to MPAs were significantly larger than the total population of lobsters tagged in the control areas. However, from the available data, it could not be established whether this difference was due to lobsters being larger when venturing out from control areas, or larger due to growth while being protected in MPAs after immigration (see below).

Spillover movement patterns, as inferred from recoveries, varied among study sites and likely reflect how these areas differ in design and bathymetry. In Kvernskjær, there were some directional trends in movement out from the MPA and control area. Most MPA lobsters moving out from the MPA apparently did not cross the trench between the MPA and control area, but moved both north, east and south of the MPA. The control area lobsters also mainly did not cross the trench, with many lobsters moving west and north and with only a few individuals being recaptured on the other side of the trench. Similar patterns in movement could not be seen in Bolærne, where the MPA and the control area were situated around the same island group, the Bolærne Islands. Both MPA and control lobsters were widely spread around the archipelago, with some higher concentrations of MPA and control lobsters in proximity to their respective areas of origin. Interestingly, sea map studies of the bathymetric profile around the Bolærne Islands indicate the possibility of a lobster habitat corridor between the MPA and control area. Consequently, the Bolærne study site had considerably more cases of reciprocal movement between MPA and control area than the other 2 sites. The relatively high density of recoveries in proximity to the island group supports that preferable habitat is extending beyond MPA and control area borders at this study site. Also, the size of the MPA may be too small to include the lobsters' full home ranges, as home range measured over a period of several years may be larger than the short-term home ranges estimated by Moland et al. (2011b) for a period of $318 \mathrm{~d}\left(<0.04 \mathrm{~km}^{2}\right)$, by Wiig et al. (2013) for a period of less than 2 mo $\left(<0.64 \mathrm{~km}^{2}\right)$ and by Skerritt et al. (2015) for a period spanning several months including spring and autumn study periods $\left(<0.01 \mathrm{~km}^{2}\right)$. By contrast, in Flødevigen, few MPA lobsters were recovered by fishers around the control area, and few control lobsters were recovered near MPA borders. Lobster recoveries were concentrated along the borders of the lobsters' original areas. The distribution of recoveries reported by fishers displayed no bias for any one area (MPA or control area) at any of the study sites. This further supports the observed movement patterns from surveyed to fished areas.

The distributions of recoveries around the different study sites indicate that depth continuity is an important factor in directing lobster movement. As one can expect that considerable changes in depth also represent a change in physical habitat (e.g. in relation to temperature), this is in accordance with earlier findings showing that movements across MPA boundaries typically occur when boundaries intersect lobster habitat (Freeman et al. 2009, Moland et al. 2011b). Earlier findings by Smith et al. (2001) also show that the spatial distribution of suitable habitat influences the spatial distribution of short-range movements in European lobster at 3 study sites on 
the south coast of England. The different distribution patterns of recovered lobsters and the differences in movement between the reserve and the control area at each site in this study emphasize the importance of evaluating habitat structure when an area is chosen for MPA designation, and also when defining the specific management goals for the area. If the goal is that the MPA should contribute to the fishery through spillover, MPA boundaries should intersect preferable habitat (Freeman et al. 2009). However, if the goal is long-term conservation of a local lobster population, it would be ideal to include entire habitat patches and take likely natural corridors for movement into consideration.

Movement from the MPAs to fished areas did not exceed movement from the control areas to fished areas either in proportion or number or by distance, yielding no indication of spillover from the MPAs. Data from Flødevigen suggest more 'spillover' from the control area than from the MPA, and this is likely due to a bigger part of the MPA being enclosed by land. A recent hypothesis also states that protectioninduced selection by marine reserves could drive long-term reductions in spillover, since spillover fisheries may gradually erode the mobile component of individuals from the population (Villegas-Ríos et al. 2017). In comparison, there was more emigration than immigration of American lobster Homarus americanus from a marine reserve located in Bonavista Bay, Newfoundland (Canada), resulting in net movement of lobster out of the reserve (spillover) (Rowe 2001). Also, harvested lobsters originating from the reserve were generally much larger than most of the other lobsters caught beyond the borders (Rowe 2001). In order to investigate whether the increased size of lobsters emigrating to the fished area from MPAs vs. control areas can compensate fishery catches for the loss of fishing grounds, it is crucial to have access to catch and effort data from the fishery. Such data were not available for the present study. On the other hand, lobsters emigrating from the MPAs to fished areas were larger than lobsters emigrating from the control area. Spillover of lobsters can contribute to increased catch in weight, even if it does not contribute to increase in numbers. Catches of European spiny lobster Palinurus elephas originating from within the Columbretes Islands marine reserve constituted a net gain of $10 \%$ to fishery yields, showing that spillover from a reserve can offset the loss of fishing grounds (Goñi et al. 2010). This study of tag-recapture modelling assumed that movement into the reserve from outside was negligible based on over an order of magnitude greater lobster density in the reserve than in the fished areas and a high density of commercial fishing effort along the boundaries of the reserve.

Targeting the largest individuals in a population has the potential to affect mating systems (Allendorf $\&$ Hard 2009). The restoration of a population's size and age structure to its natural state in a marine reserve may oppose these instabilities and lead to 'spill-in': the net immigration of individuals to a protected area due to its enhanced biological qualities. Spill-in has been discussed as a potential densitydependent effect in MPAs (Russ \& Alcala 2004, Eggleston \& Parsons 2008, Gruss et al. 2011). Few studies have examined mechanisms of such behaviour, but recent exceptions include Eggleston \& Parsons (2008) for the Caribbean spiny lobster Panulirus argus. In our study, movement between MPA and control area was most frequent in Bolærne, which had significantly more lobsters moving from the control area to the MPA than the opposite direction. Most of the movements registered had time intervals of $1 \mathrm{yr}$ or more. The lower rate of recaptured MPA lobsters in the control area may be due to fishing in the lobstering season, between sampling seasons, so without further investigation of this, it is not possible to conclude that the MPAs experience a spill-in. Lobsters moving from control areas to MPAs were significantly larger than lobsters tagged in the control area. The cause of this remains unknown, but a drive to optimize selection of potential mates might have had an effect. This is indicated by the larger size of lobsters in the MPA and by the fact that there were more female lobsters among the immigrating individuals. Female Homarus lobsters show mating preference for dominant males (Atema \& Cobb 1980, Cowan \& Atema 1990, Skog 2009), and this status is related to size (Atema 1986, Karnofsky et al. 1989). Recent work by Sørdalen et al. (2018), conducted in the Flødevigen MPA and control area using genetic parentage techniques, showed that female lobsters prefer males larger than their own size as mating partners, and that the relative size difference was significantly larger in the MPA. In the present study, larger size of immigrating lobsters may also be due to protection upon arrival in MPAs. From the available data, it cannot be established whether this difference was due to lobsters being larger when emigrating from the control area, or larger due to body growth occurring while being protected in MPAs after immigration. The attractive properties of enhanced biological qualities should be further investigated as a means to produce spill-in as an additional effect of protection. Genetic studies of parenthood combined 
with CMR surveys could reveal mating patterns, e.g. related to size, between resident and immigrant lobsters in both MPAs and control areas.

Most importantly, this study showed that lobsters moving from MPAs to fished areas were significantly larger than lobsters moving from control areas to fished areas. To what degree these larger individuals contributed to the fishery yields in terms of biomass is unknown, but this question can be assessed in future studies by combining catch and effort data from the fishery before and after MPA establishment with CMR surveys. Tag recoveries analysed in this study indicated that lobster movement is affected by bathymetric continuity and that small MPAs with borders intersecting continuous habitat may not protect the full extent of a lobster's long-term home range. Regarding future design of lobster reserves, the management goals should be considered when planning size and placement. This study supports the notion that entire habitat patches should be included if the goal is long-term conservation of a local lobster population, and that MPA boundaries should intersect preferable habitat if the goal is for the MPA to contribute to the fishery through spillover.

Acknowledgements. Long-term monitoring of the Skagerrak lobster reserves is funded by the Norwegian Institute of Marine Research through the Coastal Zone Ecosystem program. Preparation of this paper was supported by the Research Council of Norway (RCN) through the FRIPRO program (project no. 201917) by the RCN/EU funded BiodivERsA-BUFFER project, by the Regional Research Fund Agder through the CROSCON project and by a personal grant to S.H.T. from M. C. Torsø's fund. S.H.T. thanks Professor P. J. Jakobsen and K. H. M. Jensen at the University of Bergen.

\section{LITERATURE CITED}

Abesamis RA, Russ GR (2005) Density-dependent spillover from a marine reserve: long-term evidence. Ecol Appl 15: 1798-1812

Agnalt AL, Kristiansen TS, Jørstad KE (2007) Growth, reproductive cycle, and movement of berried European lobsters (Homarus gammarus) in a local stock off southwestern Norway. ICES J Mar Sci 64:288-297

* Allendorf FW, Hard JJ (2009) Human-induced evolution caused by unnatural selection through harvest of wild animals. Proc Natl Acad Sci USA 106:9987-9994

Anderson CNK, Hsieh CH, Sandin SA, Hewitt R and others (2008) Why fishing magnifies fluctuations in fish abundance. Nature 452:835-839

Atema J (1986) Review of sexual selection and chemical communication in the lobster, Homarus americanus. Can J Fish Aquat Sci 43:2283-2290

Atema J, Cobb JS (1980) Social behavior. In: Cobb JS, Phillips BF (eds) The biology and management of lob- sters. Vol I: Physiology and behavior. Academic Press Inc., San Diego, CA, p 409-450

* Bevacqua D, Melià P, Follesa MC, De Leo GA, Gatto M, Cau A (2010) Body growth and mortality of the spiny lobster Palinurus elephas within and outside a small marine protected area. Fish Res 106:543-549

* Cowan DF, Atema J (1990) Molt staggering and serial monogamy in American lobsters, Homarus americanus. Anim Behav 39:1199-1206

* Edgar GJ, Barret NS (1999) Effects of the declaration of marine reserves on Tasmanian reef fishes, invertebrates and plants. J Exp Mar Biol Ecol 242:107-144

Eggleston DB, Parsons DM (2008) Disturbance-induced 'spill-in' of Caribbean spiny lobster to marine reserves. Mar Ecol Prog Ser 371:213-220

Fenberg PB, Caselle JE, Claudet J, Clemence M and others (2012) The science of European marine reserves: status, efficacy, and future needs. Mar Policy 36:1012-1021

Follesa MC, Cuccu D, Cannas R, Sabatini A, Deiana AM, Cau A (2009) Movement patterns of the spiny lobster Palinurus elephas (Fabricius, 1787) from a central western Mediterranean protected area. Sci Mar 73:499-506

Freeman DJ, MacDiarmid AB, Taylor RB (2009) Habitat patches that cross marine reserve boundaries: consequences for the lobster Jasus edwardsii. Mar Ecol Prog Ser 388:159-167

* Galparsoro I, Borja Á, Bald J, Liria P, Chust G (2009) Predicting suitable habitat for the European lobster (Homarus gammarus), on the Basque continental shelf (Bay of Biscay), using ecological-niche factor analysis. Ecol Model 220:556-567

*Goñi R, Quetglas A, Reñones O (2006) Spillover of spiny lobsters Palinurus elephas from a marine reserve to an adjoining fishery. Mar Ecol Prog Ser 308:207-219

* Goñi R, Hilborn R, Diaz D, Mallol S, Adlerstein S (2010) Net contribution of spillover from a marine reserve to fishery catches. Mar Ecol Prog Ser 400:233-243

*Guss A, Kaplan DM, Guenette S, Roberts CM, Botsford LW (2011) Consequences of adult and juvenile movement for marine protected areas. Biol Conserv 144:692-702

* Hoskin MG, Coleman RA, Von Carlshausen E, Davis CM (2011) Variable population responses by large decapod crustaceans to the establishment of a temperate marine no-take zone. Can J Fish Aquat Sci 68:185-200

* Huserbråten MBO, Moland E, Knutsen H, Olsen EM, Andre C, Stenseth NC (2013) Conservation, spillover and gene flow within a network of northern European marine protected areas. PLOS ONE 8:e73388

Karnofsky EB, Atema J, Elgin RH (1989) Field observations of social behavior, shelter use, and foraging in the lobster, Homarus americanus. Biol Bull (Woods Hole) 176: 239-246

Kerwath SE, Winker H, Gotz A, Attwood CG (2013) Marine protected area improves yield without disadvantaging fishers. Nat Commun 4:2347

Kleiven AR, Olsen EM, Vølstad JH (2012) Total catch of a red-listed marine species is an order of magnitude higher than official data. PLOS ONE 7:e31216

Lester SE, Halpern BS, Grorud-Colvert K, Lubchenco J and others (2009) Biological effects within no-take marine reserves: a global synthesis. Mar Ecol Prog Ser 384: 33-46

* Moland E, Moland Olsen E, Knutsen H, Knutsen JA, Enersen SE, André C, Stenseth NC (2011a) Activity patterns of wild European lobster Homarus gammarus in 
coastal marine reserves: implications for future reserve design. Mar Ecol Prog Ser 429:197-207

Moland E, Olsen EM, Andvord K, Knutsen JA, Stenseth NC (2011b) Home range of European lobster (Homarus gammarus) in a marine reserve: implications for future reserve design. Can J Fish Aquat Sci 68:1197-1210

Moland E, Olsen EM, Knutsen H, Garrigou P and others (2013) Lobster and cod benefit from small-scale northern marine protected areas: inference from an empirical before-after control-impact study. Proc R Soc B 280: 20122679

Pettersen AR, Moland E, Olsen EM, Knutsen JA (2009) Lobster reserves in coastal Skagerrak - an integrated analysis of the implementation process. In: Dahl E, Moksness E, Støttrup J (eds) Integrated coastal zone management. Wiley-Blackwell Publishing, London, p 178-188

R Core Team (2014) R: a language and environment for statistical computing. R Foundation for Statistical Computing, Vienna

Roberts CM, Bohnsack JA, Gell F, Hawkins JP, Goodridge R (2001) Effects of marine reserves on adjacent fisheries. Science 294:1920-1923

Rowe S (2001) Movement and harvesting mortality of American lobsters (Homarus americanus) tagged inside and outside no-take reserves in Bonavista Bay, Newfoundland. Can J Fish Aquat Sci 58:1336-1346

Russ GR, Alcala AC (2004) Marine reserves: long-term protection is required for full recovery of predatory fish populations. Oecologia 138:622-627

Editorial responsibility: Romuald Lipcius, Gloucester Point, Virginia, USA
Skerritt DJ, Robertson PA, Mill AC, Polunin NVC, Fitzsimmons (2015) Fine scale movement, activity patterns and home-ranges of European lobster Homarus gammarus. Mar Ecol Prog Ser 536:203-219

Skog M (2009) Male but not female olfaction is crucial for intermolt mating in European lobsters (Homarus gammarus L.). Chem Senses 34:159-169

Smith IP, Jensen AC, Collins KJ, Mattey EL (2001) Movement of wild European lobsters Homarus gammarus in natural habitat. Mar Ecol Prog Ser 222:177-186

Sørdalen TK, Halvorsen K, Harrison H, Ellis C and others (2018) Harvesting changes mating behavior in European lobster. Evol Appl, doi:10.1111/eva.12611

* Triantafyllidis A, Apostolidis AP, Katsares V, Kelly E and others (2005) Mitochondrial DNA variation in the European lobster (Homarus gammarus) throughout the range. Mar Biol 146:223-235

*Villegas-Ríos D, Moland E, Olsen EM (2017) Potential of contemporary evolution to erode fishery benefits from marine reserves. Fish Fish 18:571-577

*Wiig JR, Moland E, Haugen TO, Olsen EM (2013) Spatially structured interactions between lobsters and lobster fishers in a coastal habitat: fine-scale behaviour and survival estimated from acoustic telemetry. Can J Fish Aquat Sci 70:1468-1476

Zuur AF, Ieno EN, Walker NJ, Saveliev AA, Smith GM (2009) Mixed effects modelling for nested data. In: Zuur AF, Ieno EN, Walker NJ, Saveliev AA, Smith GM (eds) Mixed effects models and extensions in ecology with R. Springer, New York, NY, p 101-142

Submitted: August 8, 2017; Accepted: March 5, 2018 Proofs received from author(s): May 6, 2018 